\title{
Florian Ferrebeuf
}

\section{THE BITTER STRUGGLE FOR THE CONTROL OF THE EAST PRUSSIAN CAMPAIGNS: THE SPD FACING CONSERVATIVE MOVEMENTS AT THE END OF THE GERMAN EMPIRE (1890-1914)}

\author{
Słowa kluczowe: $\quad$ Cesarstwo Niemieckie, polityka niemiecka, Prusy Wschodnie, niemieckie \\ partie konserwatywne, SPD \\ Schlüsselwörter: $\quad$ Deutsches Kaiserreich, Deutsche Politik, Ostpreußen, Deutsche \\ konservative Parteien, SPD \\ Keywords: $\quad$ German Empire, German Policy, East Prussia, German Conservative \\ Parties, SPD
}

Since the middle of the $19^{\text {th }}$ century and the emergence of modern political life, East Prussia countryside was largely under the control of the Prussian Konservative Partei and then of its successor, the Deutschkonservative Partei, which, as its name suggests, had more of a national vocation despite its strong roots in Prussia. The power of the Conservatives in East Prussia was obviously not anything new but it had too often overshadowed the existence of other political parties. If most of them were more present in urban areas, some of them gained significant support in the countryside as well. This was the case, until the end of the 1870s, for the Democrats or Progressists of the Deutsche Fortschrittspartei (DFP, German Progress Party), a party which ended up collapsing following many repeated assaults by Bismarck and the Prussian authorities but especially with changes in economic climate. Indeed, this party was especially acclaimed by landowners from the landowning bourgeoisie born from the abolition of serfdom and the liberalization of the land. However, the chancellor wanted to rally all the landowners to his conservative project, and he succeeded thanks to two connected actions, namely attacking head-on the political representation of the Progessists, in a first time, and in a second time coax recalcitrant landowners through a favourable economic policy. The implementation of dissuasive customs barriers and of protectionism effectively re- 
sponded to the wishes of those landowners, converted to productivist agriculture, suffering more and more, from international competition, particularly in cereals, in the early 1880s. After many delays, the landowning bourgeoisie finished to join noble landlords. An almost uniform class of landlords was thereby born which largely gathered around a conservative vision of the world and of social relations.

At the same time, the emergence of the SPD (Sozialdemokratische Partei Deutschlands, Social Democratic Party of Germany) also manifested itself during this period, and in this East Prussia was not different than the rest of Germany. This appearance is often relatively invisible in historiography, even though it was a subject of some interest for contemporaries. Nevertheless, most German conservative historians who wrote about East Prussia in the first half of the $20^{\text {th }}$ century deliberately avoided this topic. In their mind, admitting the existence of the labour movement would have been a sign of weakness. The vagaries of German political life, from the Weimar Republic (yet more favourable to the $S P D$, even in East Prussia), to the Nazi period which led to the loss of the eastern provinces of the Reich, including East Prussia, prevented the questioning of this vision. However, we will see that keeping certain localized parts of the East Prussian countryside under the conservative domination has not been as simple as it has long seemed.

The purpose of this study will therefore be to understand how the Conservatives have managed to maintain their influence on the East Prussian countries, even though the Social Democrats put an offensive strategy in place to reach them.

We will first focus on the dominance of the conservative movement in the East Prussian countries, then on the quick ascension of the SPD and finally on the ambivalence of the small and middle peasantry between these two opposing attractions.

\section{AN OLD CONSERVATIVE IMPLANTATION AND A STRONG HOLD ON THE OSTROPRUSSIAN PEASANTS}

Since the beginning of the $19^{\text {th }}$ century, the Conservatives have had an extremely strong base in the province. It found its origins in ancient traditions, inherited from a still very present Ancien Régime, while many peasants had to compensate their former lord for the prices of the land obtained following the abolition of serfdom. The subordination of the peasants towards their owners was therefore an element of importance, knowing that social relations kept a very brutal aspect until 1945. The division of the lands was done for the exclusive benefit of the lords, who obtained the best lands, while the peasants received small plots, often inherited from old tenures. The aristocracy often possessed several domains, and 
usually the largest. We should also note also that in East Prussia, the threshold of large property was fixed at 150 ha. In 1907, the district of Königsberg had the most unequal agrarian distribution in East Prussia, since only $2 \%$ of the owners owned a domain of more than 100 ha, but they owned $47.5 \%$ of the land. The $48.7 \%$ of very small peasants, own only $0.9 \%$ of the land. The situation was less unequal in the districts of Gumbinnen and Allenstein, even though the trend was similar ${ }^{1}$.

These small lands turned out in most of the cases unable of feeding a family, so small peasants had to find an additional income able to improve their lot. Many were therefore turning towards complementary activities in handicraft (wool or linen weaving, among others). Most of them had therefore to remain in the service of their former lords as an agricultural worker, permanent or seasonal, or even in another employed activity in the industries owned by the neighbouring landowner (tile-brickyard, distillery, creamery, dairy, sawmill...). The transition to salaried work was largely to the advantage of the lords, who no longer had any obligation to assist their former serfs.

This rigid social order was strengthened by a real community of values with Conservatives. The Ostroprussian population as a whole was very attached to the Prussian monarchy and to the Evangelical Lutheran religion which was that of the majority of the population, with the exception of the Catholic Warmia. It should also be pointed out that Warmian Catholics also professed conservative ideas, which did not mismatch the Lutherans ones. The piety of the Ostroprussians, especially in the most remote regions, was testified by observers.

Religiousness took on unique turns among ethnic minorities, first in Prussian Lithuania, where communities of believers (Gemeinschaft) were born at the end of the $18^{\text {th }}$ century. They prayed under the guidance of itinerant preachers (Stundenhalter), outside the structures of the Lutheran Church, which tried to prevent the development of this movement with the help of the authorities. Both believe that it was a nationalist movement aimed at the separatism of ethnic minorities. In Masuria, a similar movement developed from the 1860s, the Gromadki movement, linked to the previous one but more spontaneous, which terrified even more the Prussian administration which (mistakenly) feared the manifestation of Polish nationalism. Once this misunderstanding cleared, the movements were tolerated by the religious and civil authorities, without however benefiting from a real status as the reluctance persisted. Nevertheless, the vision of the Prussian State was not entirely wrong, since we can see in these movements the manifestation of the defence of distinctive identity of the Lithuanians and Poles from Masuria against the ger-

See W. Matull, Ostdeutschlands Arbeiterbewegung: Abriß ihrer Geschichte, Leistung und Opfer, Würzburg 1973, p. 310; A. von Batocki \& G. Schack, Bevölkerung und Wirtschaft in Ostpreußen: Untersuchungen über die Zusammenhänge zwischen Bevölkerungsentwicklung und Erwerbsgelegenheit, Jena 1929, p. 71-72. 
manization (carried out with beating drum) since the $1860 \mathrm{~s}^{2}$. Let us also point out, on the same level, that the Catholic Church came out shaken from the experience of Kulturkampf. In Warmia, Catholics and Poles were sought to be amalgamated even though more than half of Catholics are German, which initially reinforced the symbiosis of the Catholics with their clergy and their bishop, Philipp Krementz (1819-1899), who was particularly mistreated. Nevertheless, despite the failure of the Kulturkampf, the tensions between the clergy, predominantly German and the Poles led to the regrouping of the Polish community around their own clergy which was itself linked to the Polish nationalists of the Russian Empire. This overall dynamic made them impervious to German parties, which voted almost exclusively for the candidates of the Zentrum, the Catholic party emanating from the Church.

In any case, the Conservatives had real political weight outside the Warmia. Since the 1850s, the majority of seats in the Prussian Chamber of Deputies (Abgeordnetenhaus) as well as in the Reichstag had been theirs. Their power was demonstrated most strongly in the Reichstag elections, since it was the only election by universal male suffrage. All other elections were held by three-class suffrage, in which each class elected one-third of the electors ${ }^{3}$. This voting system was particularly favourable to large landowners, especially since it was largely shunned by the lower classes. However, in the 1860 s and 1870 s, many large landowners were in the ranks of the Liberals and the Democrats, who had many successes in the House. The small and middle peasantry supported the Conservatives, except during the constitutional conflict (1861-1866). This explained the success of the KP from the creation of the Reichstag (1867), in full nationalist fervour following the victory against Austria in Sadowa (1866). Consequently, the Conservatives got their hands on the province for the elections in the Reichstag, in which they always obtained at least ten seats out of seventeen between 1890 and 1918. They received the unconditional support of the authorities which begun transforming the province into a sort of archetype of the conservative province, an image it never got rid of.

\section{AGRICULTURAL SUCCESSES THAT STRENGTHEN THIS HOLD}

This political hold was due to the economic power of the large landowners, who were very predominantly conservative from the 1880s. Indeed, the creation of this conservative province must, according to the Prussian authorities, be based on agriculture, the only way of economic development possible for East Prussia given the lack of other resources. They therefore intended to favour large landowners ${ }^{4}$ as much as possible by

\footnotetext{
2 F. Ferrebeuf, Entre résistances et acculturation. Les minorités ethniques en Prusse-Orientale (1815-1920), Revue d'Allemagne et des pays de langue allemande, 2017, no. 49/1, p. 161-192.

M. Kerautret, Histoire de la Prusse, Paris 2010, p. 387-388.

4 P. Wagner, Périphéries privilégiées. La Prusse orientale en milieu rural de la fondation du Reich au national-so-
} 
persuading them to turn to intensive farming through the improvement of their infrastructure, their tools (via the purchase of increasingly sophisticated machines and chemical fertilizers), their seeds and their livestock. At the same time, the state engaged millions of thalers to renovate the road network and create an efficient rail network, then, at the turn of the century, millions to electrify the countryside that primarily benefited agricultural large estates. This concomitant action aimed to integrate latifundiaries into the commercial networks of agricultural products which was becoming global during the same period. This long-term commitment, initiated in the 1850s following the pioneering action of several agricultural associations led by Democrats, actually benefited all owners. However, this policy was the expression of the conservative approach of the agrarian structures, in order to strengthen the domination of large land ownership and for its almost exclusive benefit.

This approach quickly bore fruit, and agricultural productivity greatly increased between 1880 and 1914. The yield of wheat increased by $50 \%$ between 1880 and 1910 , those of barley, rye and oats doubled and those of potatoes increase by $150 \%$. While yields were below the national average for wheat, they were almost equivalent for rye, and dominated fairly widely for potatoes. In addition, the implementation of protectionism on a certain number of agricultural products, obtained from the State by the powerful agrarian lobbies who benefited from numerous relays within the power in place, completed the domination of the Conservatives. All this convinced a number of bourgeois owners, often Liberals or Democrats, to rally to the Conservatives from the beginning of the 1880s, all the more since their worldview and their tastes met more and more, to the point of giving birth to a class of owners reaching up to the big peasant $5^{5}$. The successes of the large ownership were anchored in the landscape with the construction, renovation, or the extension of castles or mansions that each family made a point of building. Some of the biggest owners became millionaires, like Prince Richard zu Dohna-Schlobitten (Słobity) (1843-1916), a close friend of William II who owned 9,017 ha in the circle (Kreis) of Preußisch Holland ${ }^{6}$.

The insolent success of the latifundiaries occurred at the expense of the small peasantry and the many agricultural workers. Indeed, in East Prussia, the high birth rate covered the whole of the $19^{\text {th }}$ century and the average annual growth rate was higher than 7.7\%o between 1841 and 1870; it was always above $11.2 \% 0$ between 1871 and 1905 and reached its maximum between 1891 and 1900 with

cialisme, 1871-1933, in: Histoire de l'Europe rurale contemporaine. Du village à l'État, J.-L. Mayaud \& L. Raphael (eds.), Paris 2006, p. 211-212.

5 P. Wagner, Bauern, Junker, Beamte: lokale Herrschaft und Partizipation im Ostelbien des 19. Jahrhunderts, Göttingen 2005, p. 411-412 and 443-444.

6 R. Martin, Das Jahrbuch der Millionäre Deutschlands in 20 Bänden, vol. 17: Jahrbuch des Vermögens und Einkommens der Millionäre in den Provinzen Ost- und Westpreußen, 1912, in: H. Pölking, Ostpreußen. Biographie einer Provinz, Berlin 2011, p. 283-284. 
$13.6 \% \mathrm{o}^{7}$. As a result, small peasants and agricultural workers faced intensified competition for agricultural, artisanal or small rural industry jobs, which lead many of them to emigrate as early as the 1820s. They mainly left for the industrial regions of West Germany, but even more so for the United States. The numerous epidemics of cholera, episodes of food shortage, even famine, agricultural crises, and last the increases in the prices of food products, and particularly rye, which was basic food, aggravated their situation. The end of their meagre advantages, such as the suppression of wages for threshing, agrarian problems and the harshness of social relationships were also of significant importance. The various waves of departures together reached several hundred thousand people, the majority of whom were young men. A total of 409,000 people could have left East Prussia between 1880 and 1900. As a result, population growth was barely of 50\% between 1846 and 1910 in the district of Königsberg, and the population reached 1,259,304 in 1910. The departure and roaming of agricultural workers were common to all neighbouring regions, and there were almost 260,000 itinerant workers in Eastern Europe in $1907^{8}$.

\section{BUT A HOLD BASED ON COERCION}

To develop East Prussia economically, the administration wanted to take advantage of this demographic pressure to perpetuate a low-wage economy. It supported large ownership accordingly. Initially, the explosion of emigration was not considered to be detrimental to the economic takeoff as considered, that is to say with agricultural purpose. It became so in the 1880 s, when the competition intensified at an international level, and the lack of arms started to become more and more apparent in an increasing number of agricultural fields. In any event, given the large workforce available, the average wage continued to decrease in East Prussia, dropping from $90 \%$ of the German average wage in 1867 to $60 \%$ in $1913^{9}$. Some large landowners engaged in capitalist agriculture paid their workers derisory wages. Thereby around 1892, an agricultural day labourer in the circle of Fischhausen received between 1.5 and 2.5 marks in summer, and between 1 and 2 marks in winter, according to Max Weber ${ }^{10}$. Social Democratic leader Otto Braun (1872-1955) estimated, in agreement with the provincial Chamber of Agriculture that the average salary of an agricultural worker was between 200 and 300 marks per year in $1898^{11}$.

7 M. Hubert, L'Allemagne en mutation. Histoire de la population allemande depuis 1815, Paris 1995, p. 61-64.

P. Wagner, Bauern, Junker, Beamte..., p. 388.

9 Ibidem, p. 386.

10 M. Weber, Die Verhältnisse der Landarbeiter in Deutschland, vol. 3, Die Verhältnisse der Landarbeiter im ostelbischen Deutschland, Leipzig 1892, p. 150.

11 O. Braun, Die Sozialdemokratie in Ostpreußen, Sozialistische Monatsheft, 1898, no. 7, p. 305. 
Faced with harsh working conditions and low wages, tensions grew between employers and employees, and sometimes degenerated into severe crises that did not fail to worry the Prussian administration and the elites. They reached their peak in the 1860s and 1870s, with numerous incidents in particular in Sambia (Samland), not far from Königsberg. Some landowners were thus assaulted by their employees in reaction to the violence they themselves suffered, whether symbolic or manifested in their flesh. The authorities' lack of interest in the rural condition was also revealed by their long inaction during the long episode of famine which cruelly affected Prussian Lithuania between 1867 and 1869 after many disastrous harvests and two very cold winters, preventing many works from being carried out. Malnutrition, which affected nearly 40,000 people in February 1868, led to an epidemic of typhus. The fight against famine was therefore organized around private initiatives, among others those of John Reitenbach (1816-1902), owner of the Plicken estate (disappeared, circle of Gumbinnen) or the rabbi of Memel (Klaipéda), Isaak Rülf (1831-1902), who organized aid and multiplied donations appeals.

The peak of these tensions finally occurred in the summer of 1874 in Sambia, in close connection with the circle reform (Kreisordnung) of 1872, which entrusted the police power to heads of administration (Amtsvorsteher), who were often lords or their men. However, in a circle such as Königsberg, the large landowners previously had no police power, and the legislation was therefore rightly seen as a manoeuvre intended to reinforce their power. Following the arrest of an agricultural labourer in Samitten (Dubossekowo), an actual rural revolt broke out in the cantons of Quednau (Sewernaja Gora, Kaliningrad) and Trutenau (Medwedewka), about ten kilometres north of the capital. Prisons, an abhorred symbol of the police power and of the heads of administration, were attacked, so that Patrick Wagner speaks of the "prison revolution" ("Klusen Revolution"). These events rattled local owners, while the authorities remained dumbfounded, and mobilized the army to restore calm. Finally, 200 people were arrested and brought to justice starting from October $^{12}$. Brutal social changes and the violence of social relations could therefore cause epidermic reactions from the peasants.

Despite the brutality of these various events, the Prussian administration as well as the latifundiaries struggled to understand the need to improve the rural condition. The use of coercion remained the preferred means of maintaining social order which yet continued to show signs of fragility. However, in the mid-1880s, the authorities gradually opened the door to peasants, with the implementation of a more redistributive policy towards them, well detailed by Patrick Wagner ${ }^{13}$. The provincial Public Ag-

12 P. Wagner, Bauern, Junker und Beamte..., p. 362-375.

13 P. Wagner, Périphéries privilégiées..., p. 208-209. 
ricultural Bank (Generallandschaft) which had previously concentrated its efforts on large landowners, was slowly opening up to the most modest farmers. The successes of the large owners were held up as a model and guide the investments made by all the players, at the cost of significant debt which often made all the players vulnerable.

\section{A SOCIAL DEMOCRATIC MOVEMENT OF URBAN ORIGIN, BUT EYEING THE COUNTRYSIDE}

After long years of suffering, small peasants and agricultural workers finally began to receive some small benefits from their submission, even if their docility tended to crack apart. This phenomenon was accentuated by the gradual emergence of the SPD in East Prussia ${ }^{14}$. This party has had a real influence in Königsberg since the 1870s. After several dark years following the antisocialist laws of 1878, which prohibited the Social Democratic movement, their ascent resumed from 1881 under the aegis of the locksmith August Godau (1853-1887), who relied much more clearly on workers ${ }^{15}$. Carl Schultze (1858-1897), leader of the Königsberg SPD since 1889, was finally elected to the Reichstag in $1890^{16}$.

The dismissal of Bismarck on March 20, 1890 and then the end of the anti-socialist laws in October that year reinstated the legislation of 1850. Membership of a national association remained proscribed, the organization of public meetings was restricted, open-air assemblies prohibited, and police surveillance remains as strong as ever. If socialist propaganda and the distribution of leaflets were tolerated, the newspapers were seized, and intimidation was systematic for anyone who would accept to host social democratic meetings ${ }^{17}$. Faced with the difficulty of meeting in Königsberg itself, the Social Democrats multiplied meetings outside the city walls, even if each of their meetings was dissolved by the police. These meetings, however, anchored the Social Democratic movement in the neighbouring circles of Königsberg (Königsberg-Land, Fischhausen and Labiau above all), where its influence had already been proven since the mid-1870s.

Upon his arrival, Carl Schultze put in place a real propaganda targeting the countryside, which immediately worried the authorities. Rural agitation was adapted to the local situation, and initiated by an agitation committee linked with union leader Carl Legien (1861-1920) ${ }^{18}$. The head of the agitation committee in East

14 For a global study on the Social Democratic movement in East Prussia, see - F. Ferrebeuf, Le socialisme en Prusse-Orientale sous l'Empire allemand: une réalité sous-estimée? (1871-1914), "Nordic Historical Review”, no. 17, 2013, p. 203-230.

15 W. Matull, Ostpreußens Arbeiterbewegung, Würzbourg 1970, p. 60.

16 A. Kossert, Ostpreußen. Geschichte und Mythos, Munich 2005, p. 149.

17 H. Schulze, Otto Braun oder Preußens demokratische Sendung. Eine Biographie, Frankfurt/Main 1977, p. 66.

18 W. Matull, Ostdeutschlands Arbeiterbewegung..., p. 319. 
Prussia was the carpenter Carl Lorenz $(1861-\uparrow$ ?), helped by the saddler and trade unionist Bruno Pörsch (1872-1929), originally from Korschen (Korsze, circle of Rastenburg). A brochure created by rural activists saw the light of day in 1889 , with a clear program: repeal of regulation for farmhands, reduction of working time, simplification of the rights to justice. Activists from Königsberg criss-crossed neighbouring circles every Sunday and holidays on foot or by train to distribute brochures or leaflets. Activists from the countryside were also sent to their homeland and small towns, with varying degrees of success depending on the location. The agitators adapted to the language of rural people, and left aside sensitive subjects, in particular the figures of the emperor and God. On the contrary, they bring the discussion on the elections, the right to vote or the Reichstag, of which they tried to clarify the role to the peasants ${ }^{19}$. Their propaganda particularly affected bricklayers, small artisans or workers, such as the wood workers of many sawmills. In the neighbouring circles of Königsberg, local meetings frequently bring together several tens or even hundreds of people ${ }^{20}$.

Action towards the countryside was, moreover, one of the peculiarities of Ostroprussian Social Democracy, while at the national level, the SPD was generally disinterested in the question. Only the congresses in Frankfurt/Main (October 1894) and then in Breslau (October 1895) brought the subject to the table, causing heated debates. In Frankfurt, Carl Schultze then, in Breslau, Otto Braun (18721955), who quickly became a specialist in the agrarian question, opposed the revisionist theses of the Bavarian leader Georg von Vollmar, who advocated favouring large and medium peasants in supporting their efforts to become owners. However, in East Prussia, the peasantry was largely made up of agricultural workers and day labourers who barely had the means to support themselves, and there were very few large peasants. Thanks to the support of Karl Kautsky, Braun and Schultze obtained in Breslau the rejection of Vollmar plans', so that the rural agitation remained at the initiative of local federations ${ }^{21}$. Braun and one of his close friends, the cigar maker Franz Schnell (1872-1923), took the lead of rural agitation with the full support of the new strong man of the Ostroprussian SPD, the lawyer Hugo Haase (18631919), elected in Königsberg following the death of Carl Schultze on April $1^{\text {st }}, 1897$.

19 H. Schulze, op. cit., p. 83-85 et Rapport Geheimer Staats-Archiv Preußischer Kulturbesitz (GStAPK), Berlin, XX. HA, Rep. 18, Labiau, Nr. 10, Unterdrückung der Sozialdemokratie, Report of the Regierungspräsident von der Recke, to the Landräte and to the Police of Memel, Allenstein et Braunsberg, October, 13th, 1889, folii 108-109.

20 It is the case on September $2^{\text {nd }}, 1894$ in Groß Ottenhagen (Beriozovska, circle of Königsberg-Land), where 150 people joined the meeting. Report of the Landrat of Königsberg-Land, Otto von Hüllessem-Meerscheidt, September $4^{\text {th }}, 1894$, GStAPK, XX. HA., Rep. 10, Titel 36, Nr 9, Band 1, folii 365-366.

${ }^{21}$ H. Schulze, op. cit., p. 86-88. 


\section{A SOCIAL DEMOCRATIC ACTION METHODICALLY ORGANIZED}

Propaganda was particularly effective during election campaigns. The $1^{\text {st }}$ of July 1898 for the Reichstag elections in the circle of Labiau provided a concrete example, as reflected in the report of Max Rötger, the head of the circle administration (Landrat). According to him, the entire electoral campaign in the circle would have cost almost 20,000 marks, including leaflets and brochures, the remuneration of social democratic activists who roamed through the circle riding their bicycles and the purchase of brandy for voters, a common practice in East Prussia. The magnitude of the result even surprised Haase, a candidate in the circle of Labiau-Wehlau, while the votes obtained by the Democrats, traditionally powerful in this circle, collapsed by half compared to 1893 . Those of Haase were multiplied by three, going from $8.8 \%$ to $29.8 \%$ in the first round, then to $41 \%$ in the second round ${ }^{22}$.

In order to amplify rural propaganda, Otto Braun launched on January $1^{\text {st }}$, 1899 the Ostpreußische Landbote (the Messenger of the Ostroprussian campaigns), of which he was the editor in chief $^{23}$. In a simple language, it commented on local news, informed about the action of SPD and of various assemblies. The success was instantaneous and the Ostpreußische Landbote obtained 1,700 subscriptions in its first year of existence, then reached 3,000 in a few years. Firstly monthly, it became bimonthly in September 1900 and then finally weekly a few years later. It is estimated that during this period, it was read by 12,000 to 15,000 rural residents ${ }^{24}$. In addition, the socialist press was read along with programmatic texts, brochures in the form of easily understandable stories, calendars or almanacs.

However, the successes of the Social Democrats were localized. They got their best election results in the northern half of the province. Indeed, the rural exodus of workers from these regions was in full swing in large cities like Königsberg, Memel, Insterburg (Chernyakhovsk) and Tilsit (Sovetsk). From there, they went back and forth in their villages, where they preached the good socialist word. Building from this promising implementation which extended to other more distant circles, the Social Democratic Federation of the province of Prussia organized from 1895 annual provincial congresses. Local delegates sometimes bring specific demands to the regional direction ${ }^{25}$. Out of the 23 delegates mentioned at the provincial congress of 1900 , nine were peasants and one was a fisherman ${ }^{26}$. In a multi-ethnic

\footnotetext{
268-274.

22 Report of the Landrat of Labiau Max Rötger, July $2^{\text {nd }}, 1898$, GStAPK, XX. HA, Rep. 18, Labiau, Nr. 10, folii

${ }^{23}$ The first ten numbers and another one are kept in the Secret Prussian Archives in Berlin. GStAPK, XX. HA, Rep. VI HA, Braun Otto, A 20.

${ }^{24}$ Cited in H. Schulze, op. cit., p. 89-90.

25 Three police reports of Congresses are kept in GStAPK, XX. HA, Rep. 18, Labiau, Nr. 10, for the Congresses of Königsberg (1898, folii 283-295), Danzig (1899, folii 333-349) and Königsberg (1900, folii 397-408). The Federations of West Prussia and East Prussia separated in 1900.

${ }^{26}$ They mainly came of the circles of Labiau, Gumbinnen and Tilsit, all of them in Prussian Lithuania. Report of the Congress of 1900 in Königsberg, GStAPK, XX. HA, Rep. 18, Labiau, Nr. 10, f 397.
} 
province like East Prussia, the linguistic question was of decisive importance, but it did not really seem to be a priority for the leaders, who were all German and asked the rural militants to supplement the leaflets with effective oral propaganda. However, it remained one of the main demands of the base until $1914^{27}$.

The progression in terms of votes was constant from 1890. In 1893, the SPD obtained 23,336 votes in the province (including 10,968 in Königsberg), then 45,644 votes five years later, and 55,331 in 1903, including about 30 to 35,000 from rural cantons ${ }^{28}$. On this date, the SPD became the second party of East Prussia, behind the Conservatives and their 124,170 votes, but in front of the Democrats of the Freisinnige Volkspartei ( $F V p$ ) (36,016 votes). The previous action of the Democrats was probably not insignificant in the appropriation by the peasants of a class culture, put forward by the Social Democrats themselves ${ }^{29}$ but also by historians ${ }^{30}$. In addition, for Otto Braun, the peasants and fishermen, who lived in great destitution, developed a fierce hatred for the Conservatives given the depth of their precariousness and social injustice ${ }^{31}$.

Social and agrarian structures also played an important role, because in the circles favourable to a Social Democratic implementation (Prussian Lithuania, Sambia), the number of small landowners was quite important in comparison with the centre and south circles of the province, where large landowners dominate. In Warmia and Masuria, regions populated in part by Poles where agricultural workers and micro-owners were in abundance, the conservatism prevailed very largely, as well as the will to defend its religious and linguistic particularisms especially, dealing with the germanization.

\section{... THWARTED BY THE EMERGENCE OF THE BUND DER LANDWIRTE}

Faced with the rapid rise of the $S P D$, the authorities as well as the bourgeois parties quickly soughed a way to obstruct the action of the Social Democrats, in order to maintain their influence. At the same time, the German Conservative Party $(D K P)$, the most powerful one in the Ostroprussian countryside, was disconcerted by the action of Chancellor Leo von Caprivi (1831-1899), successor to Bismarck in 1890. Caprivi wanted to reduce the taxes on cereals to facilitate imports of agricultural products into Germany and favour the exportation of German industrial products, which posed a serious threat to the agricultural sector, particularly in East

27 Report of the Congress of 1898 in Königsberg, ibidem, folii 283-295.

28 H. Schulze, op. cit., p. 92; O. Braun, Der 25. Januar in Ostpreußen, “Die Neue Zeit”, no. 20, 1907, p. 672.

29 Report of the Congress of 1898 in Königsberg, GStAPK, XX. HA, Rep. 18, Labiau, Nr. 10, fo 293.

30 P. Wagner, Périphéries privilégiées..., p. 209.

31 O. Braun, Die Sozialdemokratie in Ostpreußen..., p. 305. 
Prussia. For this, he signed free trade contracts with Russia and Austria-Hungary notably, which were unfavourable to farmers and landowners. He therefore alienated the Agrarians, who directly opposed his policy and organized a parliamentary revolt. However, the Ostroprussian conservatives had numerous relays within the power in place (ministers, senior officers or senior officials) which strengthen their ascendancy and prevented any reform trying to reduce the weight of large landowners, in agreement with the members of the provincial parliament. Incidentally, the number of large landowners among them was impressive ${ }^{32} \ldots$ Consequently, the Ostroprussian conservatives were using their connections to get the head of Caprivi, who politically finally fell under their blows in 1894 .

At the heart of the conflict between them and Caprivi, the agrarians created, at the beginning of 1893, a new organ which they wished would serve their desiderata, the Bund der Landwirte (BdL, or Agrarian League). They had a dual objective, namely to form a mass pressure group to inflect government policy in their favour, and fought Social Democracy in the field. From their foundation, the $B d L$ became a real agrarian union, demanding protectionism and a state monopoly on cereals. They defended nationalist, anti-capitalist, anti-Semitic values, hostile to industrialization and to the cities in which all farmers were able to identify; they also advocated the return to a harmonious, much idealized village society ${ }^{33}$. The $B d L$ quickly established itself as the landowners' spokesperson against the government's free trade agricultural policy, and their action was perceptible in the dismissal of Caprivi. Furthermore, the $B d L$ was an essential tool in defending all farmers' interests, including small peasants, and was in that respect very innovative.

Indeed, the Conservatives began to realize the importance of satisfying part of the demands of the agricultural workers and of the small peasantry to divert them from the emerging Social Democracy. Real efforts were therefore being made to encourage the large landowners to improve their treatment of agricultural workers and to increase their wages. Similarly, assistance was offered to small landowners in order to help them obtain loans to improve their land and infrastructure. These inflections in favour of the lower classes offered the Agrarian League instant success: as of May 1893, they had 162,000 members. They were 250,000 in 1901 and 330,000 in 1914. In $1909,178,000$ adherents came from West Germany compared to 134,000 from East. But given the position of strength of the large owners, the network in the East was much stronger, and in 1903, 17,836 of the 31,999 local associations were located in the East. One can therefore at the same time wonder which part coercion played

\footnotetext{
32 P. Wagner, Bauern, Junker und Beamte..., p. 409-411.

33 R. Aldenhoff-Hübinger, Deux pays, deux politiques agricoles? Le protectionnisme en France et en Allemagne (1880-1914), "Histoire et sociétés rurales", 2005, no. 23, p. 89-90; C. Charle, La crise des sociétés impériales, La crise des sociétés impériales: Allemagne, France, Grande-Bretagne (1900-1940), essai d’histoire comparée, Paris 2001, p. 57.
} 
in the adhesion of small peasants and agricultural workers... In any event, the $B d L$ directly competed with the SPD in this regard. In 1913, 74\% of their members were small peasants on the scale of Germany, $25 \%$ of large or medium peasants, and $1 \%$ of large landowners. The direction of the association was recruited among the latter and, at the local level, among pastors, teachers and even large farmers ${ }^{34}$. Its members put pressure on the conservative candidates, and the members of parliament formed a non-partisan group in the Reichstag. The $B d L$ also published specialized papers that provided advice to farmers while showing the beneficial action of the Conservatives. The conservative press completed its action, with the unfailing support of the State. The Ostpreußische Zeitung of Königsberg and even more the Preußischer Volksfreund (the Friend of the Prussian People) were widely distributed, sometimes free of charge, as in Masuria. This last title draws 32,700 copies, plus 2,000 in masurian language around 1900. Similarly, the Conservatives published almanacs and calendars that competed with Social Democratic publications. The most important was the Patriotischer Hauskalender, printed in 64,000 copies around $1900^{35}$.

The $B d L$ 's involvement in campaigns actually went beyond strict union action. The ideological porosity between the $D K P$ and the $B d L$ led to the $B d L$ officially committing to stand by $D K P$ 's side on an electoral level. Local agreements were concluded to make the common cause triumph for both organizations. To bring the peasants back into the conservative fold, the $B d L$ took over on their behalf $S P D$ methods in the countryside and recruited permanent members. They organized door-to-door campaigns in the villages, to massively recruit small farmers and agricultural workers. During the electoral agitation, leaflets and brochures were distributed, speakers were sent and local agricultural cooperatives receive help. These actions were clearly visible during the 1898 electoral campaign in the circle of Labiau, which we already mentioned. To face Social Democratic activists between the two rounds of the election, around forty $B d L$ members accompanied an equivalent number of activists from the German Conservative Party to distribute 4,000 leaflets ${ }^{36}$. The $B d L$ tug at the farmers' heartstrings. In this way, it could easily raise doubts among the peasants on the Social Democrats, who were head-on attacking the virulent patriotism of German society in the early $20^{\text {th }}$ century ${ }^{37}$.

If the DKP and the $B d L$ worked hand in hand most of the time, the $B d L$ 's actions sometimes clashed with the positions of the Conservatives or the (con-

${ }_{34}$ R. Aldenhoff-Hübinger, op. cit., p. 75-76; H.-J. Puhle, Agrarische Interessenpolitik und preußischer Konservatismus, Bad Godesberg 1967, p. 37-39 and 45.

35 F. Gause, Die Geschichte der Stadt Königsberg, vol. 2: Von der Königskrönung bis zum Ausbruch des Ersten Weltkrieges, Cologne 1996, p. 617; H. Schulze, op. cit., p. 92.

${ }_{36}$ Report of the Landrat of Labiau Max Rötger, July 2 $2^{\text {nd }}$, 1898, in GStAPK, XX. HA, Rep. 18, Labiau, Nr. 10, folii $270-271$.

37 H. Schulze, op. cit., p. 94-95. 
servative) government. Focused solely on defending the interests of rural people, and being above all large landowners, the Agrarian League, conceived as a union as well as a pressure group, sometimes freed itself from the program of the Conservatives by formulating specific demands. These tensions, rare in East Prussia where the majority of Conservatives were also members of the $B d L$, weakened the conservative camp. The only conflict in the Königsberg district was more the result of a personal quarrel than one of a pure ideological nature. In 1898, in the electoral constituency of Königsberg 4 (Königsberg-Land-Fischhausen), the former conservative deputy, Count August von Dönhoff, found himself prey to the wrath of the agrarian union because he supported trade agreements with Russia. The $B d L$ invested Count Georg zu Dohna-Wundlacken, soon supported by the $D K P$, from which Dönhoff was excluded. He therefore presented himself as an independent candidate with the support of the DKP members and of the other conservative party, the Deutsche Reichspartei. The Conservative division directly benefited the Social Democrats since its representative, Franz Schnell (1860-1923), was at the front in the first round and obtained $43 \%$ of the votes before Dönhoff (30.1\%) and Dohna (24.3\%). Dönhoff was finally elected in the second round, with the support of the $B d L$ and the Democrats of the $F V P^{38}$.

\section{THE SMALL PEASANTRY ATTRACTION FOR THE SPD CONDI- TIONED ON TANGIBLE RESULTS}

As this last example shows, the social democratic cause succeeded at the turn of the century in gaining support from the ranks of the small peasantry and agricultural workers. These two peasant categories were particularly attracted to the class speech put forward by the $S P D$, as by the fact that it did not hesitate to publicly denounce cases of mistreatment or to tackle the question of wages in the press emanating. The Königsberger Volkstribüne, also founded in 1893 by Otto Braun, and the Ostpreußische Landbote abound in examples of this. Likewise, the national periodicals of the SPD published, between 1890 and 1914, many theoretical articles about the social democratic Ostroprussian agitation, its effects and its pitfalls. Die Neue Zeit and the Sozialistische Monatshefte thus published articles by Otto Braun, but also by other political and trade union leaders from East Prussia, such as Karl Marchionini (1875-1926) and Adolf Hofer (1868-1935). Ostroprussian Social Democracy saw itself indeed as a bulwark of the small peasantry against its masters. One of its original features was, paradoxically, that certain party leaders were themselves landlords. We should mention in particular Max Herbig (ca. 1832-1906),

38 C.-W. Reibel, Handbuch der Reichstagswahlen 1890-1918, vol. 1, Düsseldorf 2007, p. 17-19. 
Ernst Ebhardt (1849-1831), owner of the Kommorowen estate (Komorowo, circle of Johannisburg), August Braun, owner of the Mehleden estate (Melejdy, circle of Gerdauen) from 1895 to 1904 and Adolf Hofer, owner of the Groß Skaisgirren estate (Bolshakovo, circle of Niederung). Ebhardt and August Braun also gave their peasants an interest in the benefits ${ }^{39}$.

In any event, in its early days, social democratic agitation spread a real panic among the Conservatives and the administration, and often led to violent, even hysterical reactions. It was not uncommon for activists to be greeted by groups of peasants inebriated with brandy and armed with flails, led by the local lord and pastor. Some were even chased by dogs or targeted by gunshots when they entered the private estates of the large landowners. If they managed to get through, the leaflets and newspapers were confiscated, and the peasants were closely watched. Finally, some were sometimes arrested and tried ${ }^{40}$. In addition, all assemblies were prohibited and immediately dissolved, the activists arrested at the slightest opportunity and sentenced to fines or even prison terms. The legislation was applied by the authorities to limit the action of the Social Democrats as much as possible.

A reversal took place during the electoral campaign of 1907, when the national direction of the SPD chose to oppose the massacre against the Herero in the German South West Africa, and especially to fight against the increase of agricultural prices. This program was pragmatic, since the vast majority of social democratic voters lived in cities, and were concerned by the rising cost of agricultural products. However, if the small peasantry was particularly receptive to the action of the $S P D$ when they were committed to improving their living conditions, the small peasantry remained attentive to its interests. The Ostroprussian militants, and first of all Otto Braun, instantly realized that this orientation could only harm the party in East Prussia. These choices turned out to be catastrophic for the SPD on the scale of the Reich and shattered the party's upward momentum in East Prussia, where the number of voices collapsed everywhere. Haase was defeated in Königsberg; Braun only won 3,342 votes (18.4\%) in Memel-Heydekrug and 5,316 votes (25.1\%) in Königsberg-Land-Fischhausen; Hermann Linde 3,179 votes (19.2\%) in Labiau-Wehlau to speak only of the circles previously attracted by Social Democrats ${ }^{41}$.

Raised by Otto Braun in his analysis of the 1907 electoral debacle, the question of trade unionism also deserves to be analyzed. After 1895, the SPD lost interest in agitation and in the condition of rural workers. Aware of the weakness of their supervision, Otto Braun had asked, as early as 1902, for the establishment of a fairly restrictive trade union organization for agricultural and forestry workers,

\footnotetext{
39 W. Matull, Gustav Noske und Ostpreußen, "Das Ostpreußischen Blatt", 7 juin 1968, no. 27, p. 12.

40 H. Schulze, op. cit., p. 83-85.

41 Ibidem, p. 93.
} 
with delegates able to come and explain the programs and the legislation to the peasants. Accepted by the union general commission, this measure was not applied due to the strong opposition of urban unionists. The Association of Agricultural, Forestry and Vineyard Workers (Verband der Land-, Wald- und Weinbergarbeiter) wanted by Braun was not created until 1909, after the defeat of 1907 and the rallying of a large part of the peasantry to Conservatives. The union failed to win over East Prussia, where there were only 54 members in $1911^{42}$.

Despite this decline in momentum in the countryside, the SPD remained the second political force in the province, and its fighting spirit was not undermined. The proof was that in 1912, the electoral results started to rise again slightly in certain circles. However, the dynamic seemed to have been broken in a certain number of circles, such as in Heiligenbeil-Preußisch Eylau (4.5\% against 17\% in 1903) and Rastenburg-Gerdauen-Friedland ( $8.1 \%$ against $19 \%$ in 1903). In total, at the provincial level, the SPD obtained $14.8 \%$ of the votes, against $34.8 \%$ at the national level.

\section{THE PERSISTENCE OF ECONOMIC IMPERATIVES TO THE CONSERVATIVES ADVANTAGE}

In reality, the persistence of conservative domination derived above all from the important retribution the small peasantry could draw from. And on this point, the pressure exerted by the $B d L$ on the government was successful. In 1894, the Reichstag passed a law favouring rye exportations to limit overproduction and stabilize prices. The obligation to prove the origin of cereals (often mixed with imported cereals) was lifted, and in return, farmers could obtain export compensation for customs duties in the form of import vouchers, which amounted to subsidize most of the rye production in the eastern provinces. Likewise, in 1896, a stock exchange law limiting forward transaction and prohibiting trading in grain resulted in significant gains for farmers. Finally, Agrarians and Conservatives obtained a ban in 1900 on the importation of frozen, canned or salted meats. These measures were very costly for the state, but bear fruit while allowing the farmers to compete with Russian rye internationally ${ }^{43}$. This protectionism and this legislation in favour of the agricultural world made it possible to raise prices significantly to the advantage of producers. Between 1861 and 1913, in Berlin, the price of rye increased by $17 \%$, the price of pork by $37 \%$ and that of beef by $44 \%$ while demand for meat exploded and production had never been greater ${ }^{44}$. The Agrarian League did not hesitate to

\footnotetext{
42 Ibidem, p. 97-99.

43 See B. Dedinger, Le protectionnisme est-il la clef du succès commercial allemand à la fin du XIXe siècle?, "Revue d'Allemagne et des pays de langue allemande", 2008, no. 40-41, p. 75-99.

44 P. Wagner, Bauern, Junker und Beamte..., p. 403-404.
} 
highlight its successes, which were exhibited with numerous press articles and advertising aimed at the countryside.

These various measures were voted during the peak of the results of the Social Democrats, at a time when the peasants were not yet getting any benefits. As soon as this was the case, the mentality of the peasants changed. The $B d L$ therefore established itself in a very short time as the representative of large or small farmers, which revealed the rapprochement between peasants and large owners initiated from the 1880s, the large owners being considered as "necessary enemies" and merciless oppressors ${ }^{45}$. Mentalities changed with the development of seasonal crops and the dependence of agricultural products on the international market. Despite low wages, the cohort of unemployed day labourers crisscrossing the province and the Conservatives' unwillingness to remedy these problems, the slight but real improvement in the lot of peasants in the early 1900s played a role in rallying many of them to conservative ideas. This class antagonism faded when the (small) peasants understood that their commercial interests was partly in line with those of their owners and that they needed them to obtain subventions or improve their infrastructure. They therefore accepted the domination of noble large owners in the association. In the same way, they also agreed to a more general subordination out of interest, as long as it could earn them something.

\section{THE CONSERVATIVES' VICTORY AND THE CREATION OF A NEW CONSENSUS IN THE COUNTRYSIDE}

It therefore appeared that if the attraction of part of the peasantry and agricultural workers for Social Democracy was real and sincere, it had above all been a means of pressure to their advantage. Indeed, despite the repression, or rather because of the repression of the authorities against the $S P D$, the small landowners understood that they could take advantage of the fears of the Conservatives. By turning their votes fairly massively towards the Social Democrats, they were undoubtedly trying to raise the stakes with the Conservatives, in order to obtain as many benefits as possible. When they felt they had obtained enough concessions, that their interests were threatened or the options taken by the Social Democrats were less favourable to them, they returned to the fold of the Conservatives. As a result, the small peasantry demonstrated the class consciousness mentioned above. This was the case in 1907 when, faced with the options taken by the SPD, small farmers felt threatened at a time when a number of them began to improve their living conditions. Therefore rallying to the Conservatives seemed to be the only

45 Report to the Regierungsbezirk of Köslin, cited in P. Wagner, Périphéries privilégiées..., p. 209. 
solution at their advantage to them ${ }^{46}$. While the adhesion of small farmers was undoubtedly more spontaneous, agricultural workers were also forced to join the Conservatives because of the competition engendered by the massive use of Polish seasonal workers and to preserve a potentially threatened job. This massive vote in favour of the $D K P$ has undoubtedly strengthened the image of East Prussia as a conservative province and has masked the importance gained by the SPD.

Because of their roots and their social skills, the Conservatives remained the most able to satisfy their requests, knowing that the $S P D$ was still persona non grata in political life, and that its influence in the highest levels of power was nonexistent. The Social Democrats therefore failed to perpetuate their attraction because they ultimately have nothing tangible to offer to the peasantry, unlike the Conservatives and the $B d L$. However, the points of tension persisted within the camp of the Agrarians, and undoubtedly prevented a more rapid rallying of the peasantry, the different social categories within the countryside still having divergent interests. This was particularly the case when the direction of the $B d L$ defended small owners, often meat producers, over the issue of meat prices and protectionism. This position strongly displeased the big grain farmers, who had nothing to gain from it.

All in all, the interests of these two classes converged, and allowed a new consensus to be forged in the countryside, no doubt more artificial, but clearly more rational. Indeed, now, a large part of the small peasantry was no longer fooled by its inferiority condition, and it had assimilated that it could benefit from its loyalty... and even from its disloyalty, which could prove to be as persuasive by raising the fears of the squires. The latter then looked at the peasants dreamingly, and were forced to raise the stakes to obtain their favours again. The rural voters of East Prussia, although manipulated by the big landowners, had perfectly grasped it, and knowingly returned to the fold of the lords whom they most often abhor. It was a rational choice, dictated by events, and not just a choice of adhesion or subordination as it was long believed. The vision of an undoubtedly conservative Ostroprussian rural population must therefore be measured. Its attraction for Social Democracy was therefore not entirely feigned and left traces in their electoral behaviour and even in their relations with its employers. But, faced with destitution, reason had largely taken precedence over convictions in many of them, especially since in the most remote regions, momentum is very weak.

The Ostroprussian campaigns were therefore confronted with a real ideological confrontation between 1890 and 1914, in order to convince the small peasantry and the agricultural workers of the merits of the social projects developed by the

${ }^{46}$ J.-L. Mayaud \& P. Cornu, L'agrarisme, question d'histoire urbaine?, in: J.-C. Caron \& F. Chauvaud, Les campagnes dans les sociétés européennes, Rennes, p. 33-53. 
$S P D$ on one side, and the $B d L$, the right arm of the Conservative, on the other. The old roots of the $D K P$ were widely disputed in part of the countryside, due to the hatred provoked by the omnipotence of the large landowners and social injustice. The $S P D$ enjoyed a certain windfall effect, although the conversion of many peasants to social democracy was sincere. The violent polemics that punctuated their action and the denunciations of the masters' glaring abuses offered real visibility to the struggles of small peasants, who knew that they could count on a devoted defender. The social-democratic network under construction was hitting the full force of the conservative one revived by the $B d L$, which relied, like its opponent, on intense propaganda, widely favoured by the authorities, both civil and religious.

After increasingly favourable electoral results for the $S P D$, their break with a large part of the peasant world came in 1907, due to an unfavourable strategy. The decisive rallying to the Conservatives was largely due to the formation of a new consensus in the countryside, which now included the neglected small peasants. This confirmed the idea of a conservative province, forgetting at the same time the rise of social democracy. However, it managed to plant a few seeds that will bloom again after the First World War, including in unsuspected places like the circle of Angerburg (Węgorzewo), where the results were extremely weak under the Empire.

Florian Ferrebeuf, Zaciekta walka o kontrolę nad kampaniami w Prusach Wschodnich: SPD wobec ruchów konserwatywnych u schyłku Cesarstwa Niemieckiego (1890-1914)

Streszczenie

Od połowy XIX wieku i pojawienia się nowoczesnego życia politycznego, wschodniopruska wieś znajdowała się w dużej mierze pod kontrolą pruskiej Partii Konserwatywnej (Konservative Partei), a potem jej następczyni Niemieckiej Partii Konserwatywnej (Deutschkonservative Partei), która, jak wskazuje jej nazwa, miała charakter bardziej ogólnonarodowy, pomimo silnych pruskich korzeni. Mocna pozycja konserwatystów w Prusach Wschodnich nie była w zasadzie niczym nowym, jednak często przesłaniała istnienie innych partii politycznych. Celem niniejszej pracy będzie zatem wskazanie w jaki sposób konserwatyści zdołali utrzymać swoje wpływy na wschodniopruskiej wsi, mimo, że socjaldemokraci przyjęli ofensywną stragegię, aby do niej dotrzeć. Najpierw skoncentrujemy się na dominacji ruchu konserwatywnego na wschodniopruskiej wsi, następnie na szybkim wzroście popularności SPD i wreszcie na ambiwalencji drobnego oraz średniego chłopstwa między tymi dwiema przeciwnymi opcjami.

Translated by Aleksander Pluskowski

Florian Ferrebeuf, Der harte Kampf um die Kontrolle über die Ostpreußische Operation: Die SPD angesichts der konservativen Bewegungen am Ende des Deutschen Reiches (1890-1914)

Zusammenfassung

Ab der Mitte des 19. Jahrhunderts und dem Aufkommen des modernen politischen Lebens stand das ostpreußische Dorf weitgehend unter der Kontrolle der Preußisch-Konservativen Partei und dann ihres Nachfolgers, der Deutsch-Konservativen Partei, die, wie ihr Name vermuten lässt, trotz ihrer starken preußischen Wurzeln eher national geprägt war. Die starke Stellung der Konservativen in Ostpreußen war natürlich nichts Neues, aber sie verdeckte zu oft die Existenz anderer politischer Parteien. Das Ziel der vorliegenden Arbeit ist es zu zeigen, wie es 
den Konservativen gelang, trotz der offensiven Strategie der Sozialdemokraten ihren Einfluss auf dem ostpreußischen Dorf zu bewahren. Zuerst wird die Dominanz der konservativen Bewegung auf dem ostpreußischen Dorf besprochen, dann der rasante Zuwachs der Beliebtheit der SPD und die Ambivalenz der kleinen und mittleren Landbevölkerung zwischen diesen beiden gegensätzlichen Optionen.

Übersetzt von Emilia Figura-Osełkowska

Florian Ferrebeuf

Doctor in Contemporary History

Associate researcher at the DynamE Laboratory

University of Strasbourg

florian.ferrebeuf@gmail.com

BIBLIOGRAPHY

Primary Sources:

- $\quad$ Geheimer Staats-Archiv Preußischer Kulturbesitz (GStAPK), Berlin, XX. HA, Rep. VI HA, Braun Otto, A 20.

- $\quad$ GStAPK, XX. HA, Rep. 18, Labiau, Nr. 10, Unterdrückung der Sozialdemokratie, Report of the Regierungspräsident von der Recke, to the Landräte and to the Police of Memel, Allenstein and Braunsberg, October, $13^{\text {th }}, 1889$, folii $108-109$.

- $\quad$ GStAPK, XX. HA., Rep. 10, Titel 36, Nr 9, Band 1, Report of the Landrat of Königsberg-Land Otto von Hüllessem-Meerscheidt, September $4^{\text {th }}, 1894$, folii 365-366.

- $\quad$ GStAPK, XX. HA, Rep. 18, Labiau, Nr. 10, Report of the Landrat of Labiau Max Rötger, July $2^{\text {nd }}, 1898$, folii 268-274.

- $\quad$ GStAPK, XX. HA, Rep. 18, Labiau, Nr. 10, SPD Congresses of Königsberg (1898, folii 283-295), Danzig (1899, folii 333-349) and Königsberg (1900, folii 397-408).

\section{Secondary Sources:}

von Batocki Adolf \& Schack Gerhard,

1929 Bevölkerung und Wirtschaft in Ostpreußen: Untersuchungen über die Zusammenhänge zwischen Bevölkerungsentwicklung und Erwerbsgelegenheit, Jena.

Braun Otto

1898 Die Sozialdemokratie in Ostpreußen, Sozialistische Monatsheft, no. 7.

1907 Der 25. Januar in Ostpreußen, Die Neue Zeit, no. 20.

Martin Rudolf

1912 Das Jahrbuch der Millionäre Deutschlands in 20 Bänden, vol. XVII : Jahrbuch des Vermögens und Einkommens der Millionäre in den Provinzen Ost- und Westpreußen.

Weber Max

1892 Die Verhältnisse der Landarbeiter in Deutschland, vol. 3: Die Verhältnisse der Landarbeiter im ostelbischen Deutschland, Leipzig.

\section{Studies:}

Aldenhoff-Hübinger Rita

2005 Deux pays, deux politiques agricoles? Le protectionnisme en France et en Allemagne (1880-1914), Histoire et sociétés rurales, no. 23.

Charle Christophe

2001 La crise des sociétés impériales, La crise des sociétés impériales: Allemagne, France, Grande-Bretagne (19001940), essai d'histoire comparée, Paris.

Dedinger Béatrice

2008 Le protectionnisme est-il la clef du succès commercial allemand à la fin du XIX ${ }^{e}$ siècle?, Revue d'Allemagne et des pays de langue allemande, no. 40-41. 
Ferrebeuf Florian

2013 Le socialisme en Prusse-Orientale sous l'Empire allemand: une réalité sous-estimée” (1871-1914)», „Nordic Historical Review", no. 17.

2017 Entre résistances et acculturation. Les minorités ethniques en Prusse-Orientale (1815-1920), „Revue d'Allemagne et des pays de langue allemande", no. 49/1.

Gause Fritz

1996 Die Geschichte der Stadt Königsberg, vol. 2 : Von der Königskrönung bis zum Ausbruch des Ersten Weltkrieges, Cologne.

Hubert Michel

1995 L'Allemagne en mutation. Histoire de la population allemande depuis 1815, Paris.

Kerautret Michel

2010 Histoire de la Prusse, Paris.

Kossert Andreas

2005 Ostpreußen. Geschichte und Mythos, Munich.

Matull Wilhelm,

1968 Gustav Noske und Ostpreußen, Das Ostpreußischen Blatt, June $7^{\text {th }}$, 1968, no. 27.

1970 Ostpreußens Arbeiterbewegung, Würzbourg.

1973 Ostdeutschlands Arbeiterbewegung: Abriß ihrer Geschichte, Leistung und Opfer, Würzburg.

Mayaud Jean-Luc and Cornu Pierre

2005 L'agrarisme, question d'histoire urbaine?, in: J.-C. Caron, F. Chauvaud, Les campagnes dans les sociétés européennes, Rennes.

Pölking Hermann

2011 Ostpreußen. Biographie einer Provinz, Berlin.

Puhle Hans-Jürgen

1967 Agrarische Interessenpolitik und preußischer Konservatismus, Schriftenreihe des Forschungsinstituts der Friedrich-Ebert-Stiftung, Bad Godesberg.

Reibel Carl-Wilhelm

2007 Handbuch der Reichstagswahlen 1890-1918, vol. 1, Düsseldorf.

Schulze Hagen

1977 Otto Braun oder Preußens demokratische Sendung. Eine Biographie, Frankfurt/Main.

Wagner Patrick

2005 Bauern, Junker, Beamte: lokale Herrschaft und Partizipation im Ostelbien des 19. Jahrhunderts, Göttingen.

2006 Périphéries privilégiées. La Prusse orientale en milieu rural de la fondation du Reich au national-socialisme, 1871-1933, in: J.-L. Mayaud \& R. Lutz (eds.), Histoire de l'Europe rurale contemporaine. Du village à l'État, Paris. 